\title{
IMMIGRATION CONTROLS: \\ WHY THE SELF-DETERMINATION ARGUMENT IS SELF-DEFEATING
}

\author{
Maxime Lepoutre \\ University of Cambridge \\ Forthcoming in Journal of Social Philosophy
}

\section{Introduction}

Immigration designates the process whereby people move from one state into another for the purposes of temporary or permanent settlement. ${ }^{1}$ Policy responses to immigration raise the politically salient question of how open the territorial borders of states should be to potential immigrants. In addressing this question, most theoretical debates assume that states and their citizenry have a right to unilaterally control their borders - the territorial right to exclude. They then ask how that right ought to be exercised in light of the needs and interests of would-be immigrants. Advocates of open borders who take this approach argue that even if a state has a right to unilaterally control its territorial borders, exercising this right by closing its borders to would-be immigrants would be wrong or unjustified. ${ }^{2}$ Increasingly, however, the debate has begun to examine whether states have such a unilateral territorial right to exclude outsiders in the first place. ${ }^{3}$

The present article focuses on the latter issue. Further, since its subject is immigration as opposed to other forms of transborder movement, such as tourism - it considers the unilateral right to exclude outsiders from settling in a given territory. Why examine this issue? Isn't the more common question - that is, the question of whether particular immigration controls set by a state are morally justifiable - more important than the question of whether a state is entitled to set its border policy unilaterally? 
Although the first question is indeed highly important, the second question matters greatly nonetheless. In the first place, when adopting a critical stance towards contemporary states' immigration practices, as the present article will do, considering it is dialectically advantageous. The claim that given immigration controls are acceptable depends on the moral justification of the controls themselves - how well they respond to the competing claims of would-be immigrants and residents - but also on whether the controls came about through the right procedure. Just as an otherwise laudable law may plausibly be deemed illegitimate if imposed by a dictator, so immigration controls seem unacceptable if they are legislated by a group that lacks the right to do so unilaterally. Hence, while one way to criticize given immigration controls is to cast doubt on their intrinsic moral standing, another is to show that they are typically introduced through procedures that exclude some who ought to have a say. Complementing the former approach with the latter only enriches and strengthens critiques of contemporary states' immigration practices.

Secondly, and more positively, interrogating the assertion that states have a right to unilaterally set their border policy introduces more explicitly a political dimension to ethical discussions of immigration controls. By bringing to the foreground the issue of who should have a say in deciding what border policies should be implemented, this line of inquiry helps us think more clearly about what the appropriate political arena is for raising and debating competing views regarding border controls. ${ }^{4}$ So, investigating this question not only opens up further possibilities for critically assessing contemporary immigration policies, but it also supplies positive guidance regarding how we should reform political institutions to determine the shape of border policies in the future. ${ }^{5}$

In the context of this important second question, then, I will concentrate specifically on the argument that a given state's citizenry has a unilateral right to exclude would-be immigrants by virtue of its right to self-determination. This "self-determination argument" 
warrants close examination, given that it is one of the most commonly invoked arguments, both in political discourse and in political philosophy, for why states allegedly have such a right. ${ }^{6}$ Put more precisely, the self-determination argument for why a specific group G possesses the right to exclude runs as follows.

Bounded Self thesis: Territorially-bounded group $G$ has the right to determine itself, which includes the right to determine its membership, or civic boundaries.

Territorial thesis: This right to self-determination grounds a right to unilaterally control the territorial borders of the state that contains G.

So, $\mathrm{G}$ has the right to unilaterally control the borders of this state.

I refer to the problem of justifying the Bounded Self thesis as the Problem of the Self. ${ }^{7}$ Thus, addressing the Problem of the Self requires demonstrating that a given territorially-bounded group has such a right to self-determination. The problem of justifying the Territorial thesis is the Territorial Problem.

With this background in place, I aim to show that attempts to address either of these two problems reveal that the self-determination argument faces serious - if not insurmountable difficulties deriving from a common source, the Coercion Principle. According to the Coercion Principle, all persons subjected to coercive political power are entitled to participate as equals in determining how that power is exercised. By appealing to this principle, Arash Abizadeh has famously criticized attempts to address the Problem of the Self. ${ }^{8}$ However, and as we will see, his criticism has recently met with significant resistance. In this context, the 
purpose of the present article is to challenge the self-determination argument partly by defending Abizadeh's charge, and partly by deepening it in order to remediate its limitations and produce a more intractable challenge. Indeed, not only will I uphold the claim that the Coercion Principle undermines some strategies for addressing the Problem of the Self against recent critics, but I will also demonstrate the novel thesis that the Coercion Principle is bound to be presupposed by answers to the Territorial Problem in such a way as to render the selfdetermination argument self-defeating.

The rest of this article is organized as follows. First, after considering answers to the Problem of the Self that conceptualize the self as politically-constituted, I defend Abizadeh's argument that this strategy fails because of democratic theory's reliance on the Coercion Principle (Section 1). Nevertheless, even with this defense in place, Abizadeh's objection remains vulnerable: in particular, it is possible to circumvent his objection by specifying the self pre-politically. For this reason, I then demonstrate that attempts to justify the Territorial thesis also presuppose the Coercion Principle's truth. Hence, whichever way one tries to specify the self, the self-determination argument is bound to rely on the Coercion Principle (Section 2). Finally, by showing territorial borders to be coercive to many outsiders, I establish that the Coercion Principle opposes the right to unilaterally control one's territorial borders. Thus, the self-determination argument is self-defeating: attempts to justify its premises are bound to rely on a principle which in fact conflicts with its conclusion, and thereby internally undermines it (Section 3).

\section{The Politically-Bounded Self and the Coercion Principle}

For proponents of the self-determination argument, there are two ways of addressing the Problem of the Self. First, one might identify a pre-political group defined by cultural and/or 
historical ties, and argue that it has the right to determine itself via the state's political agency. Alternatively, one might assert that the group entitled to self-determination is politically constituted.

The latter strategy may seem more appealing insofar as it avoids skepticism regarding the existence of pre-political selves, ${ }^{9}$ and circumvents the difficulties involved in establishing the congruence between the pre-political self and state boundaries. ${ }^{10}$ Accordingly, I first consider the political route to answering the Problem of the Self. To say that the self is politically constituted means that the civic boundaries which delineate it are defined by political procedures or political principles. Since the aim here is to specify a self that has the right to self-determination, and because this right is commonly associated with the democratic political ideal, this approach to the Problem of the Self typically involves showing that democratic theory can identify a territorially-bounded group that has the right to determine itself.

\subsection{The Unbounded Demos}

A first way to constitute the self politically is by determining the civic boundaries which define it through democratic procedures. However, a familiar criticism of this approach is that it is viciously circular. To determine the bounds of the self-determining group through democratic procedures, we must know who has a right to participate in democratic decisionmaking. But this is what the procedure was intended to determine. From this observation, Whelan concludes that "democracy, which is a method for group decision-making or selfgovernance, cannot be brought to bear on the logically prior matter of the constitution of the group itself, the existence of which it presupposes". ${ }^{11}$ 
Nevertheless, Whelan's conclusion is too quick: even if democratic procedures cannot specify the bounded self, normative principles internal to democratic theory might allow us to do so. ${ }^{12}$ On this approach, democratic theory's principles identify constitutive presuppositions of democratic procedures which provide criteria for determining who has a right to participate, and thus who the bounded self comprises.

However, as Abizadeh has recently argued, democratic principles in fact do not seem to justify setting boundaries on political participation. According to Abizadeh, the fundamental democratic principle is the Coercion Principle. This principle states that all those subjected to coercive political power should be included in the demos, so that they have the right to participate as equals in determining how that power is exercised. Indeed, for Abizadeh, democratic theory is fundamentally premised on the basic freedom and moral equality of individuals. Responding to this freedom and equality requires giving equal consideration to persons' autonomy. Therefore, given that coercion tends to severely reduce the personal autonomy of those who are coerced, democratic theory holds that respecting the autonomy of individuals subjected to political coercion requires granting them the right to participate politically as equals in determining how that coercion is exercised. ${ }^{13}$

Now, the Coercion Principle fails to justify restricting the self-determining group to a territorially-bounded unit. Indeed, it renders the demos in principle unbounded: if persons outside territorial borders were subjected to political power exercised by those inside, then, according to the Coercion Principle, they would have political participation rights. Therefore, the first upshot of democratic theory's reliance on this principle is that other grounds than democratic standards are needed to restrict the self to a territorially-bounded unit and justify the Bounded Self thesis.

Furthermore, and more significantly, the Coercion Principle not only does not justify, but in fact opposes the Bounded Self thesis. This is because "civic boundaries pose by their very 
nature an externality problem: [...] the act of constituting boundaries circumscribing political rights is always an exercise of power over both insiders and outsiders that [...] purports to disenfranchise the outsiders over whom power is exercised." 14 This is especially true if - as proponents of the self-determination argument want to argue - membership involves a right to unilaterally control the group's territorial borders. ${ }^{15}$ Consequently, the Coercion Principle demands that the constitution of civic boundaries, which regulate membership, be democratically justified to insiders and outsiders, so that there can be no unilateral right for a group to set its civic boundaries. In sum, combined with the claim that establishing and controlling civic and territorial boundaries is coercive to outsiders, democratic theory's Coercion Principle opposes the existence of a territorially-bounded self that is selfdetermining in the sense of having the right to unilaterally determine its shape and membership.

Now, this argument for why the political strategy fails to justify the Bounded Self thesis might seem problematic for several reasons. In 1.2, I will respond to a criticism of the conditional claim that if one takes the Coercion Principle to be a central principle of democratic theory, then democratic theory opposes the Bounded Self thesis. But in the meantime, a more immediate worry concerns the antecedent of this claim: Abizadeh's assertion that the Coercion Principle is a fundamental democratic principle may appear overly hasty and contentious. Indeed, while it is not uncommon for democratic theorists to endorse a version of the Coercion Principle, ${ }^{16}$ many alternative principles specifying who should be included in the demos have been suggested by theorists working on the democratic boundary problem - that is, the problem of who belongs to the demos.

For the purposes of my argument, however, this theoretical controversy is relatively unproblematic. This is because the most plausible alternative democratic principles of inclusion share the Coercion Principle's crucial recommendation (discussed at greater length 
below) that very many outsiders, including destitute would-be immigrants, should have a say in controlling a state's civic and territorial boundaries. Indeed, the most prominent rival principle is the All-Affected Principle, which claims that all and only those who are affected by a state decision should have a say in making that decision. ${ }^{17}$ Since individuals who are coerced by a state decision are a subset of those affected by that decision, the All-Affected Principle would support the Coercion Principle's above recommendation. Hence, Abizadeh's argument, as well as mine, would still go through even if we accepted this alternative principle instead. So, in the context of our discussion, controversies within the literature on the democratic boundary problem are broadly ${ }^{18}$ unproblematic for the suggestion that we take the Coercion Principle to be a fundamental tenet of democratic theory.

Even so, one might harbor reservations regarding the Coercion Principle's plausibility. Let us briefly consider two such worries. To begin, the principle may appear to have the following counterintuitive implication: if Germany wanted to annex Poland, the Coercion Principle seemingly entails that Poles may not forcibly resist this annexation unless this resistance is approved of in a democratic decision where both Poles and Germans have an equal say. While this would be an unpalatable result, advocates of the Coercion Principle can respond in two ways. Firstly, the annexation of Poland by Germany would in the first instance subject Poles to coercion, not Germans. Hence, the Coercion Principle requires that there be a prior democratic decision where all and only those subjected to coercion (i.e., Poles) have a say in deciding whether the annexation should occur in the first place. Unless they also wanted the annexation, Poles would presumably decide against the merger. Secondly, if this prior decision does not occur, or if Germany goes forward with the annexation regardless, then it seems plausible to think that in unjustly annexing Poland, Germans have waived their right to participate in the subsequent decision regarding whether the annexation might be forcibly resisted. Although these two lines of response would need to 
be spelled out in greater detail, they suggest that the Coercion Principle need not have the above undesirable implication.

A second worry is more foundational. According to Richard Arneson, having a democratic say in a decision $\mathrm{D}$ involves having some measure of coercive power over other people who are subjected to D. But "there is no [...] basic moral right to exercise significant power over the lives of other people, to direct how they shall live their lives". ${ }^{19}$ So, whereas the Coercion Principle moves from the wrongness of coercion to the claim that those subjected to coercion have a right to a democratic say, Arneson seemingly takes the wrongness of coercion to point in exactly the opposite direction. Accordingly, the rationale for the Coercion Principle seems obscure.

In fact, however, upon closer examination, Arneson's position can be reconciled with appreciating the Coercion Principle's appeal. Notice that in context, Arneson is denying that there is a basic right to a democratic say, a right that is non-derivatively or noninstrumentally justified. Again, this is because in itself, it is pro tanto morally problematic to exercise coercive power over other autonomous human beings. But Arneson accepts that a right to a democratic say can be justified instrumentally, when its pro tanto wrongness is overridden by its benefits. ${ }^{20}$

With this observation in mind, recall that the Coercion Principle says that when agent $A$ is subjected to coercive power by $B$, she is entitled to participate, alongside other subjects of that power, in deciding how it is exercised. So the Coercion Principle does not suggest introducing entirely new instances of coercion where there were none. Rather, it recommends changing the procedures for deciding how existing coercive power is exercised. While this does mean that A ends up having some coercive power over others, Arneson may well think that replacing B's unilateral power over A with a situation where A, B, and all other subjects of the power have a say is a moral improvement, all things considered. A strong rationale for 
thinking that the new situation is better overall is that since all subjects of coercive power have some influence over how it is used, they can exercise checks on one another. This

reduces the likelihood that the coercive power in question will be employed arbitrarily. ${ }^{21}$ And intuitively, arbitrary coercive power is morally worse and more inimical to personal autonomy than non-arbitrary power. Therefore, even if, like Arneson, one thinks that having a democratic say is intrinsically morally problematic because it involves exercising coercive power over others, granting individuals a right to a democratic say in the way required by the Coercion Principle may well be justified overall. Once more, this is because it tends to transform arbitrary coercive power into non-arbitrary coercive power. ${ }^{22}$

Let us take stock. Abizadeh argues that the political strategy for justifying the Bounded Self thesis fails because of democratic theory's reliance on the Coercion Principle. Contra potential critics, I have defended the plausibility of taking the Coercion Principle to be a fundamental thesis of democratic theory. In Section 2, I will go beyond Abizadeh and offer an argument that should be appealing even to those who remain unconvinced that the Coercion Principle lies at the heart of the democratic ideal. Indeed, as advertised in the introduction, I will show that the Coercion Principle is also presupposed by proponents of the self-determination argument at a later stage, when justifying the Territoral thesis. But before doing so, I uphold Abizadeh's critique of the political strategy against a second type of objection.

\subsection{Defending the Unbounded Demos}

A powerful objection to Abizadeh's above argument asserts that the democratic ideal does not reduce to the Coercion Principle. It involves further internal standards, which justify restricting the self-determining demos to a territorially-bounded group. Accordingly, for 
Sarah Song, the basic democratic value is political equality. Political equality, she suggests, requires the formal participatory rights guaranteed by the Coercion Principle, but also that certain substantive conditions be met. First, having real opportunities to participate politically as equals requires a certain measure of resource equality. Second, sincere and respectful deliberation between equals requires interpersonal solidarity and trust. Securing these substantive conditions of democracy necessitates a stable and shared culture. The modern territorially-bounded state, Song concludes, picks out such a stable and culturally-defined demos. $^{23}$

This argument has two problems. First, such cultural and territorial boundaries on the demos are not constitutive of the democratic ideal of political equality. This ideal says that moral equals subjected to political power have a right to participate politically as equals. It therefore asserts something about (1) who has a right to political equality and (2) what that political equality involves. Song's two substantive conditions of political equality correspond to the second element, and are therefore indeed constitutive of democracy. However, bounding the demos into a stable culturally-homogeneous group is not: though it may advance the substantive conditions of political equality, it does so at the expense of its first constitutive component. Indeed, given the "externality problem" posed by civic and territorial boundaries, restricting the demos that controls them to a culturally-homogeneous state excludes some individuals who are subjected to coercive political power. Song's mistake, then, is this: though she correctly affirms that genuine political equality requires that certain substantive conditions be satisfied, she overlooks the fact that this does not change who is entitled to such equality. Accordingly, unless the democratic ideal is incoherent, a stable and culturally-homogeneous demos cannot be a constitutive presupposition of democracy. Instead, such a restriction on the demos is a way of realizing substantive political equality between some individuals in circumstances where both constitutive conditions of democratic 
political equality cannot simultaneously be satisfied. But since democratic theory itself is silent on which of its constitutive conditions we should privilege in such circumstances, ${ }^{24}$ it alone does not justify such a restriction.

Second, suppose we conceded that in non-ideal circumstances where both constitutive conditions cannot be realized, democratic theory did justify restricting the demos to achieve substantive political equality, at the cost of not including everyone who is subjected to coercive political power. Because we are considering an argument for a territorially-bounded group's unilateral territorial right to exclude, Song would still have to establish the stronger claim that the restriction needed to achieve substantive political equality excludes all wouldbe immigrants from the bounded self.

However, this stronger claim seems implausible. First, one might deny that solidarity and trust require cultural similarity. ${ }^{25}$ But even if they do, there is significant cross-border cultural overlap, and invariably significant internal cultural variation within states. ${ }^{26}$ Consequently, not only does it seem unlikely that the levels of cultural homogeneity required for substantive political equality justify excluding all would-be immigrants, but Song could not argue for this conclusion without also implying that many resident citizens of current states need to be excluded.

Even so, couldn't Song respond that solidarity also requires group stability and that extending political rights to any would-be immigrants would undermine such stability? ${ }^{27}$ This response seems empirically contentious. As Fine has observed, even in the absence of outsider participation, state populations are generally not as stable as Song suggests: "the population is always in flux, as generations pass on, some members emigrate, and children become fully participating members". ${ }^{28}$ The fact that this does not threaten solidarity and its constituent norms of reciprocity suggests that solidarity is continuously recreated and is not necessarily the result of a long history of interaction amongst a stable group. As a result, 
contra Song, it seems implausible to think that extending political rights to some would-be immigrants would undermine group stability in such a way as to prevent norms of solidarity from developing.

In sum, I have upheld the plausibility of Abizadeh's assertion that because of its reliance on the Coercion Principle, and even in light of its further internal standards, democratic theory does not justify the Bounded Self thesis. Indeed, because it does not support excluding all potential immigrants from the self-determining group it defines, this group is not territorially-bounded. Consequently, unless it can be shown that border controls are in fact not coercive to outsiders - an objection I consider in Section 3 - the political strategy to addressing the Problem of the Self fails.

\section{The Pre-Political Self and the Coercion Principle}

Justifying the Bounded Self thesis by appealing to democratic theory's political principles is unpromising because democratic theory, it is plausible to think, relies on the Coercion Principle. To circumvent this objection, advocates of the self-determination argument might attempt to address the Problem of the Self by identifying a pre-political self, whose bounds

are specified by principles external to democratic theory. ${ }^{29} \mathrm{I}$ will argue that this attempt at evading the problem is ultimately unsuccessful, because the self-determination argument also relies on the Coercion Principle at a later stage, when justifying the Territorial thesis. In virtue of establishing this novel thesis, my critique of the self-determination argument has greater scope and is more intractable than Abizadeh's in two important ways. It demonstrates that the Coercion Principle generates profound difficulties even for 1) those who employ the pre-political strategy for justifying the Bounded Self thesis, and 2) those who remain doubtful - contra Section 1 - that the Coercion Principle lies at the heart of the democratic ideal. 


\subsection{The Pre-Political Self}

The most influential attempt to specify a pre-political territorially-bounded self that has the right to self-determination is the cultural-nationalist approach theorized by David Miller. Briefly put, on this view, the self is determined by a shared national identity consisting of shared beliefs, historical continuity, a common public culture, and attachment to a geographical location. ${ }^{30}$ Because national identity involves attachment to a given territory, it seems to pick out the kind of territorially-bounded group that the Bounded Self thesis refers to. Further, national identity is taken to be ethically relevant: because it "provides [its members] with a background against which more individual choices about how to live can be made", ${ }^{31}$ members of a nation have a powerful interest in maintaining their national culture, which grounds a right to self-determination. This right allows the nation to collectively define and carry out its projects through political institutions. Finally, since a crucial national project is determining who the self is, nations thereby have a right to set the terms of membership. ${ }^{32}$

Now, as mentioned earlier, the notion of a pre-political self is not uncontroversial. Some express skepticism about the possibility of specifying determinate nations without resorting to cultural reification. ${ }^{33}$ Others claim that it is unlikely that nations will coincide with states' territorial borders, so that, given the current state system, the interest in preserving national identity cannot justify granting a given nation a territorial right to exclude. ${ }^{34}$

Nevertheless, I wish to set aside these worries and concede that they are not insuperable for the cultural-nationalist approach. Instead, I will argue that this alternative answer to the Problem of the Self only temporarily avoids the problem posed by the Coercion Principle. To begin, recall that - assuming that border controls are coercive to outsiders - the Coercion Principle not only does not justify the Bounded Self thesis, but also opposes it. However, I grant for the time being that the interest in national self-determination - or whatever grounds 
are given for the pre-political self - can override the Coercion Principle's appeal and justify the Bounded Self thesis. What I will now show is that even if we grant this, the Coercion Principle undermines the self-determination argument at another level: justifications for the Territorial thesis are bound to presuppose the Coercion Principle in such a way as to render the self-determination argument self-defeating.

\subsection{The Territorial Problem and the Coercion Principle}

Let us assume that there exists a pre-political territorially-bounded self that has the right to determine itself. The Territorial thesis then asserts that this right grounds a right to unilaterally control the territory's boundaries. But what justifies this thesis? At first glance, the mere presence of non-members on a territory does not seem to directly impede the self's determination of its future shape and projects. ${ }^{35}$ The right to self-determination consequently does not seem to directly entail a territorial right to exclude.

To establish the Territorial thesis, the self-determination argument therefore appeals to a further premise. This is most clearly expressed by Walzer's "principle of political justice". This principle states that persons settled in a territory ought to be granted citizenship rights, including political participation rights, because such residents are systematically subjected to

political power. ${ }^{36}$ Now, unlike tourists, immigrants by definition settle in a territory. Hence, a group's ability to control its membership depends on its ability to control immigration, as immigrants must be granted citizenship rights. Thus, because the principle of political justice demands that civic boundaries be extended to include residents, a group's right to determine its shape and civic boundaries entails a right to unilaterally control who comes to reside in its territory, and therefore entails a right to unilaterally control its territorial borders. ${ }^{37}$ 
Importantly, this justification of the link between the right to self-determination and the right to unilaterally control one's own territorial borders is not specific to Walzer, but is widespread amongst proponents of the self-determination argument. ${ }^{38}$ Miller, for instance, puts forth a version of this justification. In line with Walzer's principle of political justice, he argues that in order to avoid the creation of a category of second-class citizens, which would be profoundly illiberal, residents subjected to state power must be granted equal citizenship rights. ${ }^{39}$ Now, liberal nation-states are committed to realizing social justice, and this involves granting citizens not merely formal political rights, but also extensive socioeconomic rights. As a result, high levels of immigration risk increasing the cost of social welfare policies. Moreover, if immigration levels are so high that mutual cultural adjustment cannot take place, the communal solidarity necessary to sustain welfare spending may weaken. ${ }^{40}$ As such, given that residents must be granted equal membership rights, high levels of immigration threaten social welfare programs. But such programs are constitutive of a national commitment to realizing social justice. Therefore, for Miller, national self-determination - which involves determining the self's shape and pursuing national projects - requires controlling immigration levels. $^{41}$

The problem for the self-determination argument is now clear. The principle of political justice affirms that because residents are subjected to political power, it would be tyrannical or illiberal not to grant them membership rights. But this just is the Coercion Principle, applied restrictively to state residents. ${ }^{42}$ Therefore, if the Coercion Principle opposes unilateral control over territorial borders, and if the Territorial thesis' justification presupposes the Coercion Principle, then this principle internally undermines the self-determination argument. To explain: this argument's defenders can no longer assert that although the Coercion Principle opposes the territorial right to exclude, the value of national self-determination overrides this principle. This is because the inference from the right to self-determination to 
the territorial right to exclude is only plausible insofar as the principle of political justice is compelling, and that principle is itself only plausible insofar as the more general Coercion Principle is. Thus, if the Coercion Principle opposes the territorial right to exclude, the selfdetermination argument is rendered self-defeating: because it implicitly relies on the Coercion Principle, it can be no more compelling than the principle that entails a denial of its conclusion.

Two replies are available to the proponent of the self-determination argument. The first consists in objecting that the Territorial thesis does not necessarily rely on the Coercion Principle. The second denies that doing so is problematic, by arguing that territorial border controls are in fact not coercive to outsiders, and that the Coercion Principle therefore does not oppose granting a territorially-bounded group the right to unilaterally control its borders. The rest of this essay addresses these objections in turn.

\subsection{Is the Objection Ad Hominem?}

A first reply is that my challenge is merely ad hominem. Though proponents of the selfdetermination argument do appeal - explicitly or tacitly - to the principle of political justice which itself relies on the Coercion Principle, they need not do so. In fact, the objection continues, closer attention to my presentation of the self-determination argument suggests another way of justifying the Territorial thesis.

The self-determination argument outlined in the previous section appeals to the fact that residents are subjected to power exercised by the self-determining group over a given territory. Now, a territorial right to exclude cannot derive from the principle of political justice in conjunction with brute exercise of power over a given territory and its residents, as that would amount to claiming that might makes right. Consequently, this argument 
presupposes not merely that the self-determining group exercises political power over a territory, but also that it is entitled to do so. Thus, the right to self-determination deriving from pre-political grounds is taken to include a right to territorial jurisdiction - a right to "make and enforce rules over a bounded geographical area" ${ }^{43}$ - prior to any appeal to the principle of political justice. But if these pre-political grounds can directly justify some territorial rights, why can't they directly justify a territorial right to exclude as well?

In fact, as Ypi argues, the right to exclude is more difficult to justify than other territorial rights. ${ }^{44}$ Consider again the cultural-nationalist argument for the right to self-determination. This right derives from the interest in preserving national identity. Further, national identity is bound up with a specific territory that the nation has transformed materially and symbolically, so that its "members develop a collective attachment to a land that becomes inseparable [sic] part of who they are". ${ }^{45}$ This symbolic value grounds a consequentialist argument for granting rights of territorial jurisdiction and to manage natural resources as components of the right to self-determination. Such rights give members "continuing access to places that are especially significant to them, and it allows choices to be made over how these sites are to be protected and managed" ${ }^{46}$ In this way, these rights allow the preservation of the symbolic value that the land possesses as a constituent of the nation's identity.

However, this cultural-nationalist argument seems incapable of directly justifying a territorial right to exclude. First, it is unclear why the mere presence of others would detract from land's symbolic value for a group, and so why the interest in preserving this value justifies a right to exclude. One prominent suggestion is that overcrowding risks damaging national landmarks. ${ }^{47}$ Since the territorial exclusion of individuals is necessary to prevent overcrowding, it is therefore required as a means of protecting national identity.

Here, I will not dispute the premise that if immigration, by generating overcrowding, damages national landmarks, then the value of national identity supplies powerful reasons for 
granting the national group a territorial right to exclude. But even conceding this, the 'overcrowding' argument relies on an assumption that is empirically dubious. Indeed, Ypi has observed that valuable sites that have been declared UNESCO "Common Heritage of Humanity" are often better protected than those that have not, even though they are visited by immense numbers of tourists. ${ }^{48}$ What this example suggests is that national landmarks can be adequately protected in spite of overcrowding. Accordingly, on the evidence Ypi supplies, which is corroborated for instance by Janna Thompson, ${ }^{49}$ preventing overcrowding is not a necessary condition for protecting symbolically valuable sites. Thus, even if immigration were liable to lead to high population densities, protecting national identity would not necessitate granting the relevant group a unilateral right to control its borders.

One might object that Ypi's reply is overly hasty, or at least inadequate for our purposes. Firstly, her UNESCO example is about tourists, not immigrants. This might seem problematic, since I stated earlier that this paper is concerned with immigration rather than tourism. While this is true, what matters here is less whether the individuals in question are tourists or immigrants, and more that there are extremely many of them in the vicinity of national landmarks. This is sufficient to cast doubt on the claim that a necessary empirical connection obtains between overcrowding and damage to symbolically valuable sites.

A second worry is that countries with UNESCO sites currently do have border controls in place. So perhaps we cannot infer from Ypi's example that national landmarks could be protected in the absence of exclusionary practices. Once more, however, this needn't undercut my argument. Even if countries with UNESCO sites have border controls, it remains true that the cultural sites they possess are visited by immense numbers of individuals. So, these cases can still be used to weaken the purported connection between overcrowding and damage to national landmarks. Now, I cannot rule out in principle the possibility that without territorial exclusions, there might arise overcrowding so intense that traditional methods of protecting 
national landmarks are no longer efficacious. But even so, the fact that existing cases of overcrowding need not be damaging provides defeasible grounds for finding this empirical assumption suspect. ${ }^{50}$

Nonetheless, both worries bring out the fact that my opposition to this empirical assumption should be qualified, as follows: I do not purport to have definitively established that national landmarks can always be protected in the face of overcrowding, even in the absence of border controls. But the existence of clear instances where national landmarks are very well protected despite high population densities does serve to shift the burden of proof. Absent further arguments to the extent 1) that immigrants are more likely to damage symbolically valuable sites than tourists or 2) that the population densities that would arise in the absence of territorial exclusions would be so high that symbolically valuable sites could not be protected in the way that UNESCO sites currently are, we should be unmoved by the 'overcrowding' argument.

The problems for proponents of the unilateral territorial right to exclude do not end there. Even if immigration were bound to reduce the symbolic value of land for a given group, a consequentialist argument for the territorial right to exclude would still not immediately follow. Indeed, because land is often symbolically valuable to more than one group, granting a single nation a right to exclude has often generated conflict and thereby engendered disastrous consequences. ${ }^{51}$ Finally, appealing to land's material value instead cannot help the cultural-nationalist: that a group has enhanced land's material value does not provide a consequentialist argument for excluding others from it unless it can be shown that these others would not similarly generate material value. ${ }^{52}$

In light of these special difficulties, it seems an attractive feature of the self-determination argument outlined in Section 2.2 that, by appealing to the principle of political justice, it infers the unilateral right to exclude from more easily-justifiable rights to territorial 
jurisdiction. Hence, it is more plausible to see this argument as a response to the difficulty of directly inferring a territorial right to exclude from the right to self-determination's prepolitical grounds, than to see the latter type of argument as an alternative to the former. This provides reasons to think that the self-determination argument is bound to appeal to the principle of political justice when justifying its Territorial thesis.

To summarize, Sections 1 and 2 have shown that however the self-determination argument addresses the Problem of the Self, it is undermined by the Coercion Principle if border controls are coercive to outsiders. Since it necessarily relies on the Coercion Principle - either when addressing the Problem of the Self, or when answering the Territorial Problem - it must establish that this principle in fact does not oppose a unilateral right for the state to control its own territorial borders, by showing that such controls are not coercive. In what follows, I consider and invalidate this line of argument, as recently articulated by David Miller.

\section{The Coerciveness of Border Controls}

\subsection{Autonomy and Coercion}

As discussed in Section 1, Abizadeh takes the Coercion Principle to be grounded in the value of autonomy. On this view, which David Miller also accepts, ${ }^{53}$ because coercion is particularly damaging to autonomy, subjecting persons to coercion is compatible with respecting their autonomy and hence morally acceptable only if they have a right to a democratic say. The idea is that having a democratic say - where this involves having not only equal voting power but also an equal opportunity to participate in processes of public justification - helps individuals hold those who exercise coercive power accountable. Thus, according to proponents of this view, democratic participation reduces the extent to which 
individuals are subjected to arbitrary coercive power, and so helps them retain some measure of control over how their lives go. ${ }^{54}$ In this light, to ascertain whether border controls are coercive to would-be immigrants, we must first determine what autonomy consists of, and how coercion violates it.

According to Raz's influential account, autonomy has three main components. A person is autonomous just in case she has the mental capacities required to form and revise projects (Psychological condition), has an adequate range of options to choose from (Adequacy-ofOptions condition), and is independent in the sense of not being subjected to the will of another (Independence condition). ${ }^{55}$

How does coercion affect autonomy? Briefly put, A coerces B when, by employing or threatening to employ physical force, A intentionally creates a worse choice situation for B as a means of forcing B to do what A wants. Put differently, A deliberately restricts B's options to make B act in conformity with A's will. Hence, coercion damages autonomy in two ways. First, it inherently reduces the range of options available to the coercee, sometimes to the point of leaving the coercee with an inadequate range. One's range of options is inadequate, for Raz, when one's choice is dictated by personal needs. Personal needs are "what is necessary to have the life one has or has set upon". ${ }^{56}$ Second, because coercion involves the intention of making the coercee into an instrument of one's will, it always violates the Independence condition. By virtue of involving such an intention, coercion, unlike natural catastrophes, constitutes a "direct assault" on autonomy, which explains why it triggers a demand for democratic participation. ${ }^{57}$ Having clarified what constitutes coercion, do territorial border controls coerce outsiders? 


\subsection{Border Controls and the Adequacy-of-Options condition}

Territorial border controls undeniably restrict outsiders' range of options. Most obviously, they reduce their freedom of movement by raising physical barriers ranging from fences and electric wires to police dogs and shooting on sight. ${ }^{58}$ Nevertheless, to constitute a violation of autonomy, border controls must restrict the range of options available to outsiders to an inadequate level, where one has at most one option capable of furnishing what is necessary to pursue one's central projects. Now, restricting freedom of movement does not invariably have this effect. Indeed, it is often curtailed within states without anyone claiming that a vital interest has been injured. ${ }^{59}$ However, in many cases, would-be immigrants' states of origin fail to provide them with an adequate range of options. This is the case not only of individuals who are persecuted in their original states, but also of those fleeing natural calamities or domestic situations characterized by dire economic deprivation. ${ }^{60}$ In such cases, exercising border controls does seem to restrict would-be immigrants' options to an inadequate range.

Miller, however, denies that this is so. He remarks that when a single state closes its borders to those situated in dire circumstances, "there are many other states that this person can apply to enter, including many richer states". ${ }^{61}$ A first response is that even if Miller's reply were correct, it fails to justify states' unilateral right to exclude. His argument is that a state's border controls do not violate the Adequacy-of-Options condition because immigrants may immigrate elsewhere. But for any state, whether this is true depends on other states' border policies. So, whether a state has a right to close its borders depends on other states' policies. Consequently, states lack a unilateral right to exclude: to avoid violating the Adequacy-of-Options condition, they must coordinate their border policies with those of other states. 
Second, the empirical accuracy of Miller's reply is questionable. In some cases, it is simply false that there are many other states would-be immigrants can apply to. Consider for instance the European Union's 1990 Dublin Convention. By affirming that asylum-seekers may only apply to immigrate in the first member state that they entered, this convention considerably reduces the number of other states to which they can apply. ${ }^{62}$ Further, as Fine has noted, "the interests in living in state A are not always interchangeable with the interests in living in state B or state C." ${ }^{63}$ Indeed, only admission to a particular state will allow me to be reunited with my family, or with a territorially-concentrated religious group. Now, having the opportunity to realize such aims may very well be crucial to living a life that I recognize as my own, and therefore intuitively seems to constitute a personal need. In such cases, then, a single state's border controls do indeed violate the Adequacy-of-Options condition for some would-be immigrants.

\subsection{Border Controls and the Independence condition}

Border controls, I have argued, can in many cases reduce the range of options available to potential immigrants to inadequate levels. Nonetheless, one might respond that even if some border controls have this effect, violating the Adequacy-of-Options condition is not sufficient to constitute coercion. Indeed, though a natural disaster may drastically reduce one's options, natural disasters are not coercive. This is because, as discussed in 3.1, coercion always involves objectionable intentions that violate autonomy's Independence condition.

Now, Miller also denies that border controls violate the Independence condition. Even if states collectively violate the Adequacy-of-Options condition through their border controls, there is no collective intention to do so. Each state that refuses entry to would-be immigrants intends simply that they not enter its territory, not that they not migrate at all. Similarly, one 
might add, even in the above-discussed cases where a single state's border controls suffice to violate the Adequacy-of-Options condition, such a state intends only to prevent would-be immigrants from entering its territory. Consequently, for Miller, the intentional subordination of the will that constitutes the specific evil of coercion is absent in the case of border controls. ${ }^{64}$

However, this objection is misleading. While violating the Adequacy-of-Options condition requires reducing someone's options to an inadequate range, violating the Independence condition does not require that one intend to restrict someone's options below the adequacy threshold. The coercer need only intend $a$ restriction of the coercee's options as a means of making the coercee act in conformity with his or her will. ${ }^{65}$ To see this, consider a master who threatens to physically punish a slave should he try to escape, but otherwise leaves him many options. Though this master does not intend to reduce the slave's options to inadequate levels, the slave's independence is intuitively violated by the master's intention of restricting his options to make him refrain from escaping. This is significant, because Miller's objection is based on the observation that there is no intention to reduce would-be immigrants' options to an inadequate range. In light of the above, we can accept this observation and nonetheless maintain that single states' border policies do involve an intention that violates the Independence condition by making potential immigrants into instruments of their will. In controlling their borders, states invariably intend to restrict would-be immigrants' options as a means of getting them to advance the state's ends by refraining from crossing the border unauthorized. Thus, border controls all involve "credible threats of physical force [that] compromise the coercee's independence because they threaten to use her body for purposes that are not her own."66

Consequently, Section 3.2 showed that border controls violate the Adequacy-of-Options condition for some would-be immigrants, while Section 3.3 established that they violate the 
Independence condition for all possible would-be immigrants. Hence, even if we assume that violating both the Independence and the Adequacy-of-Options conditions is necessary for coercion - contra Raz and Abizadeh, for whom violating the Independence condition suffices for coercion ${ }^{67}$ - it still follows that border controls systematically coerce some would-be immigrants, though they do not coerce wealthy tourists or well-off would-be immigrants. Therefore, the Coercion Principle demands that some would-be immigrants have a right to participate in border policy-making, and thus opposes states' claim to a right to unilaterally control their own borders.

At this point, one might object that this conclusion retreats substantially from Abizadeh's radical thesis that immigration controls coerce all would-be immigrants, so that the Coercion Principle mandates the inclusion of all would-be immigrants in border policy-making. Thus, this objection continues, I have defended the coerciveness of border controls only at the cost of weakening the claim Miller originally criticized. ${ }^{68}$

While this is true, it should not obscure the fact that my conclusion remains a very strong one, which deeply upsets the self-determination argument. Indeed, my conclusion is not only that according to the Coercion Principle - which the self-determination argument presupposes - some would-be immigrants should participate in the border policy-making of states they wish to enter. Notice that flows of persons escaping war, persecution and economic destitution by moving to affluent western states - persons, that is, whose options would be reduced to inadequate levels by a decision to close those states' borders - are extremely numerous and steeply increasing. ${ }^{69}$ So, in the overwhelming majority of cases that have been the focus of political and media attention, my argument entails that a very high and increasing number of would-be immigrants should be included in border policy-making. This is a powerful result: the Coercion Principle internally undermines the self-determination argument 
in very many high-profile cases. And these are precisely the cases where the selfdetermination argument is typically invoked.

\section{Conclusion}

I have argued that the self-determination argument for the right to unilaterally control one's territorial borders is internally undermined by the Coercion Principle. However this argument addresses the Problem of the Self, it is bound to rely on this principle. On the one hand, since one of the core ideas of democratic theory is that autonomous beings should not be subjected to coercive power without having a say in how it is exercised, specifying the self politically will plausibly appeal to a variant of this principle. On the other, specifying the self pre-politically fails to evade this problem, because a similar issue arises one step further down the argumentative line, when justifying the Territorial thesis: even if the Bounded Self thesis could be justified, the inference from the right to self-determination to the territorial right to exclude relies on the Coercion Principle. Finally, since border controls coerce very many would-be immigrants, the self-determination argument's reliance on this principle renders it self-defeating. Or more precisely, it renders it self-defeating in the numerous instances where would-be immigrants are subjected to coercion.

This argument has two noteworthy upshots. First, in addition to defending Abizadeh's argument against detractors, I have extended it significantly. Abizadeh suggests that democratic theory opposes the Bounded Self thesis. But it is compatible with this conclusion that such a thesis may be justified by pre-political principles external to democratic theory, provided that the moral force of these principles outweighs that of the Coercion Principle. My argument rules out this possibility, by suggesting that even such pre-political arguments rely on the Coercion Principle when justifying the Territorial thesis. A limitation of this extension 
is that I cannot rule out a priori the existence of alternative justifications that do not do so. Nevertheless, I have shown that the main attempts to derive the unilateral territorial right to exclude from the right to self-determination rely on this principle, and that attempts to directly derive the right to exclude from the grounds that justify the right to selfdetermination encounter severe difficulties.

So, in virtue of giving strong grounds for thinking that the Coercion Principle is also at play in justifications of the Territorial thesis, my argument has greater scope than Abizadeh's in two respects. It should have traction with those who (in spite of my defense) remain unconvinced by Abizadeh's claim that the Coercion Principle is a core principle of democratic theory, so that the political strategy of justifying the Bounded Self thesis fails. And it should be compelling even against those who accept Abizadeh's claim but attempt to circumvent it by specifying the self pre-politically.

Second, and more programmatically, the fact that the ideal of self-determination cannot coherently support a unilateral territorial right to exclude should urge us to rethink the concept of collective self-determination. Briefly put, and as Iris Marion Young once argued, self-determination should be seen less as a matter of possessing a sphere of freedom from interference, and more as consisting of freedom from arbitrary interference. ${ }^{70}$ Considered in this way, self-determination requires not exclusive control over a territory, as defenders of the self-determination argument have tried to argue, but rather the right to participate politically in all exercises of power to which one is subjected.

\section{ACKNOWLEDGEMENTS}

For helpful feedback on previous drafts, I am grateful to David Miller, Clare Chambers, Luke J. Davies, Matthias Brinkmann, Graham Bex-Priestley, Diana Popescu, two anonymous 
Journal of Social Philosophy reviewers, and, for comments on multiple drafts, Joanna Demaree-Cotton.

\section{NOTES}

1 This definition is taken from Chandran Kukathas, "The Case for Open Immigration," in Contemporary Debates in Applied Ethics, ed. Andrew Cohen and Christopher Wellman (Malden, MA: Blackwell, 2005), 208.

${ }^{2}$ See, e.g., David Miller, National Responsibility and Global Justice (Oxford: Oxford University Press, 2007), 222-224; Kukathas, "The Case for Open Immigration," 210-211; Joseph Carens, The Ethics of Immigration (Oxford: Oxford University Press, 2013), esp. ch.1-10; Lea Ypi, "Justice in Migration: A Closed Borders Utopia?," Journal of Political Philosophy 16, no. 4 (2008). Often, this approach assumes that there can be a right to do wrong, as famously defended in Jeremy Waldron, "A Right to Do Wrong," Ethics 92, no. 1 (1981). This makes it possible to criticize states' border policies as being wrong or unjustified even while acknowledging that they have a right to exercise it in that way. However, this is not invariably so: in the final two substantive chapters of The Ethics of Immigration (chs.11-12), Carens argues from the fact that certain border controls are morally unjustified to the claim that the state's unilateral right to control its borders is not "discretionary", or does not include the right to implement unjustifiably restrictive border controls. But even then, Carens does not challenge the claim that the state and its citizenry have a unilateral right to control its borders.

${ }^{3}$ For this more recent approach, see Arash Abizadeh, "Democratic Theory and Border Coercion: No Right to Unilaterally Control Your Own Borders," Political Theory 36, no. 1 (2008); Lea Ypi, "Territorial Rights and Exclusion," Philosophy Compass 8, no. 3 (2013); Sarah Fine, "The Ethics of Immigration: Self-Determination and the Right to Exclude," Philosophy Compass 8, no. 3 (2013); Chandran Kukathas, "Why Open Borders?," Ethical Perspectives 19, no. 4 (2012).

${ }^{4}$ Abizadeh, "Democratic Theory and Border Coercion," 38-39.

${ }^{5}$ Thanks to an anonymous reviewer for pressing me to clarify this.

${ }^{6}$ Versions of this argument are notably advanced by Michael Walzer, Spheres of justice : a defence of pluralism and equality (New York: Basic Books, 1983), 61-63; Miller, National Responsibility and Global Justice, 222; Christopher Wellman, "Immigration and Freedom of Association," Ethics 119, no. 1 (2008): 114-115; Frederick
} 
Whelan, "Citizenship and Freedom of Movement," in Open Borders? Closed Societies?, ed. Mark Gibney (New York, NY: Greenwood, 1988), 28.

${ }^{7}$ In naming this problem thus, I follow Fine, "The Ethics of Immigration: Self-Determination and the Right to Exclude," 264-265.

${ }^{8}$ Abizadeh, "Democratic Theory and Border Coercion," 41-48.

${ }^{9}$ For an example of such skepticism, see: Arash Abizadeh, "On the Demos and its Kin: Nationalism, Democracy, and the Boundary Problem," The American Political Science Review 106, no. 4 (2012): 881. Although he of course does not share this skepticism, David Miller himself also regards it as an advantage of the political strategy that it avoids the worries raised by such skeptics. See David Miller, "Democracy's Domain," Philosophy \& Public Affairs 37, no. 3 (2009): 203-204.

${ }^{10}$ Fine, "The Ethics of Immigration: Self-Determination and the Right to Exclude," 264.

${ }^{11}$ Frederick Whelan, "Prologue: Democratic Theory and the Boundary Problem," in Nomos XXV: Liberal Democracy, ed. James Pennock and John Chapman (New York, NY: New York University Press, 1983), 40. See also: Miller, "Democracy's Domain," 203-204.

${ }^{12}$ Miller, "Democracy's Domain," 204.

${ }^{13}$ Abizadeh, "Democratic Theory and Border Coercion," 40-41. For further discussion of the relation between coercion, autonomy, and democracy, see Section 3.1, including note 51.

${ }^{14}$ Abizadeh, "On the Demos and its Kin: Nationalism, Democracy, and the Boundary Problem," 876-877.

${ }^{15}$ Abizadeh, "Democratic Theory and Border Coercion," 46.

${ }^{16}$ E.g., Nancy Fraser, "Who Counts? Dilemmas of Justice in a Postwestphalian World," Antipode 41, no. S1 (2009).

${ }^{17}$ For proponents of the All-Affected Principle, see: Iris Marion Young, Inclusion and democracy (Oxford: Oxford University Press, 2000); Ian Shapiro, Democratic Justice (New Haven, CT: Yale University Press, 1999); Robert Goodin, "Enfranchising All Affected Interests, and Its Alternatives," Philosophy \& Public Affairs 35, no. 1 (2007); Laura Valentini, "No Global Demos, No Global Democracy? A Systematization and Critique," American Political Science Association 12, no. 4 (2014); and David Held, "Democratic Accountability and Political Effectiveness from a Cosmopolitan Perspective," Government and Opposition 39, no. 2 (2004): 373375.

${ }^{18}$ I say 'broadly' because some suggested democratic principles of inclusion are more restrictive and do not entail that would-be immigrants should have a say in controlling a state's civic and territorial borders. However, 
Valentini and Abizadeh have elsewhere persuasively argued that the restrictiveness of these principles is ad hoc and therefore morally indefensible. For examples of more restrictive principles see: See, e.g., Claudio LópezGuerra, "Should Expatriates Vote?," Journal of Political Philosophy 13, no. 2 (2005); and Ludvig Beckman, The Frontiers of Democracy: The Right to Vote and its Limits (New York, NY: Palgrave Macmillan, 2009). For compelling rebuttals, see: Valentini, "No Global Demos, No Global Democracy? A Systematization and Critique," 792; and Abizadeh, "On the Demos and its Kin: Nationalism, Democracy, and the Boundary Problem," 878.

${ }^{19}$ Richard Arneson, "Democracy is not intrinsically just," in Justice and Democracy: Essays for Brian Barry, eds. Keith Dowding et al (Cambridge: Cambridge University Press, 2004), 46-48.

${ }^{20}$ This point is especially clear in Richard Arneson, "Debate: Defending the Purely Instrumental Account of Democratic Legitimacy," Journal of Political Philosophy 11, no. 1 (2003): 124-126.

${ }^{21}$ See, e.g., Ian Shapiro, The State of Democratic Theory (New Haven, CT: Yale University Press, 2003), ch.2.

${ }^{22}$ Thanks to two anonymous reviewers for suggesting these objections.

${ }^{23}$ Sarah Song, "The boundary problem in democratic theory: why the demos should be bounded by the state," International Theory 4, no. 1 (2012): 43-48, 58-60.

${ }^{24}$ For instance, by contrast with Song, Sarah Fine, "Democracy, citizenship, and the bits in between," Critical Review of International Social and Political Philosophy 14, no. 5 (2011): 631, privileges democratic inclusion over substantive equ-ality. In conditions where both constitutive conditions of democracy cannot be fully satisfied, she suggests that the democratic ideal first and foremost recommends extending the franchise to all of those subjected to political power.

${ }^{25}$ See, e.g., Arash Abizadeh, "Does Liberal Democracy Presuppose a Cultural Nation? Four Arguments," The American Political Science Review 96, no. 3 (2002).

${ }^{26}$ Abizadeh, "On the Demos and its Kin: Nationalism, Democracy, and the Boundary Problem," 870.

${ }^{27}$ Song, "The boundary problem in democratic theory: why the demos should be bounded by the state," 56-57.

${ }^{28}$ Fine, "Democracy, citizenship, and the bits in between," 601. See also: Will Kymlicka, "Immigration, Citizenship, Multiculturalism: Exploring the Links," The Political Quarterly 74, no. 1 (2003).

${ }^{29}$ Miller, "Democracy's Domain," 202.

${ }^{30}$ David Miller, On Nationality (Oxford: Oxford University Press, 1995), 21-27.

${ }^{31}$ Ibid, 86. 
${ }^{32}$ See, e.g., Miller, National Responsibility and Global Justice, 222-224; Wellman, "Immigration and Freedom of Association," 114-115; and Walzer, Spheres of justice, 61-62.

${ }^{33}$ Abizadeh, "On the Demos and its Kin: Nationalism, Democracy, and the Boundary Problem," 869-871. See also: Chantal Mouffe, "Carl Schmitt and the Paradox of Liberal Democracy," in The Challenge of Carl Schmitt, ed. Chantal. Mouffe (London: Verso, 1999), 50.

${ }^{34}$ Fine, "The Ethics of Immigration: Self-Determination and the Right to Exclude," 264.

${ }^{35}$ Ibid, 258-259.

${ }^{36}$ Walzer, Spheres of justice, 60.

${ }^{37}$ Ibid, 58-62.

${ }^{38}$ For a structurally similar argument, see: Wellman, "Immigration and Freedom of Association," 125-126; David Miller, "Immigrants, Nations, and Citizenship," The Journal of Political Philosophy 16, no. 4 (2008): 375-378; and Ypi, "Justice in Migration: A Closed Borders Utopia?," 398-399. This strategy is also discussed by Rainer Bauböck, "Global Justice, Freedom of Movement and Democratic Citizenship," European Journal of Sociology 50, no. 1 (2009): 12, and Fine, "The Ethics of Immigration: Self-Determination and the Right to Exclude," 259.

${ }^{39}$ Miller, "Immigrants, Nations, and Citizenship," 375-378.

${ }^{40}$ Miller, On Nationality, 128-129.

${ }^{41}$ Miller, National Responsibility and Global Justice, 222-224. Note that although my presentation of Miller's argument focuses on the national project of realizing social justice, a similar observation holds for many other national projects he mentions when justifying the right to unilaterally set immigration policy. For instance, David Miller suggests that nations must be able to set an immigration policy to control their population's size, age profile, and the mix of skills their workforce contains. But immigration would not affect the mix of skills available in the nation's workforce if immigrants were not granted membership rights including the right to work. Similarly, their presence on the same territory would not affect the nation's size and age profile unless they were members of the nation. Thus, as in the case of social justice, Miller's claim that realizing these projects requires being able to control immigration flows presupposes that all residents must be granted membership rights.

${ }^{42}$ T.H. Marshall, "Citizenship and Social Class," in Inequality and Society, ed. Jeff Manza and Michael Sauder (New York, NY: W.W. Norton and Co., 2009) distinguishes between civil, social, and political citizenship rights. In this light, one might worry that the principle of political justice is in fact not a restricted application of 
the Coercion Principle: whereas the principle of political justice claims that those subjected to the law should be granted equal citizenship rights generally construed - as is particularly clear in Miller's argument - the Coercion Principle makes the more restricted claim that they should be granted political citizenship rights. However, this worry is misguided. Marshall's distinction is fundamentally historical, rather than normative. Accordingly, political, social and civil citizenship rights are normatively much closer than their historical origins suggest. As discussed above, genuine political equality requires a measure of socioeconomic equality and therefore presupposes social and civil citizenship rights. Conversely, Jürgen Habermas, "On the Internal Relation between the Rule of Law and Democracy," The Inclusion of the Other (1998), 253-264, and Nancy Fraser, Scales of justice : reimagining political space in a globalizing world (Cambridge: Polity, 2008), 12-29, have argued that social and civil rights cannot be stably secured without adequate political representation. Hence, because the Coercion Principle demands political representation on terms of equality, it also calls for social and civil citizenship rights.

${ }^{43}$ Ypi, "Territorial Rights and Exclusion," 242-243.

${ }^{44}$ Ibid.

${ }^{45}$ Ibid, 247. For a more extensive discussion of the symbolic value of land, see Hein Goemans, "Bounded communities: territoriality, territorial attachment, and conflict," in Territoriality and Conflict in an Era of Globalization, ed. Miles Kahler and Barbara Walter (Cambridge: Cambridge University Press, 2006).

${ }^{46}$ Miller, National Responsibility and Global Justice, 219.

${ }^{47}$ Ibid, 223.

${ }^{48}$ Ypi, "Territorial Rights and Exclusion," 248.

49 See Janna Thompson, Taking Responsibility for the Past (Cambridge: Polity Press, 2002), 61-65. For further details on how overcrowded sites are protected, see Arhur Pederson, "Managing Tourism at World Heritage Sites," Unesco World Heritage Centre (2002), http://whc.unesco.org/uploads/activities/documents/activity-1132.pdf.

${ }^{50} \mathrm{I}$ am grateful to an anonymous reviewer for raising these worries.

${ }^{51}$ Young, Inclusion and democracy, 260-261.

${ }^{52}$ A limitation of my argument here is that the fact that a group has enhanced the material value of land could be understood as grounding a non-consequentialist Lockean justification for a territorial right to exclude: by virtue of increasing the value of land through their members' labor, nations come to deserve the land (see, for instance, John Simmons, "On the Territorial Rights of States," Philosophical Issues 11(2001), and Cara Nine, "A 
Lockean Theory of Territory," Political Studies 56, no. 1 (2008)). I set aside this alternative mode of justifying a territorial right to exclude for two reasons. In the first place, I take Anna Stilz, "Why do states have territorial rights?," International Theory 1, no. 2 (2009): 186-194, and Ypi, "Territorial Rights and Exclusion," 243-246, to have provided convincing refutations of it. Secondly, and more fundamentally, even if a Lockean account of territorial rights were in principle capable of justifying a territorial right to exclude, it would be of little use to proponents of the self-determination argument. This is because, as Simmons, "On the Territorial Rights of States," 315 , himself recognizes, the overwhelming majority of current states did not acquire their territory in a way that satisfied the Lockean conditions for legitimacy. As a result, this account cannot be used to justify current states' right to unilaterally control their territorial borders. Importantly, this second consideration also applies to other non-consequentialist justifications for territorial rights. Stilz's prominent Kantian account, for instance, stipulates that a state's claim to territory is rightful only if that state did not "usurp" the territory. But given the historical injustices involved in the formation of current states, it seems few current states would met this condition. See Stilz, "Why do states have territorial rights?," 198.

${ }^{53}$ Miller, "Why Immigration Controls are Not Coercive," 112.

${ }^{54}$ For this relation between democratic inclusion and the protection of personal autonomy, see for instance: Rainer Forst, "Political Liberty: Integrating Five Conceptions of Autonomy," in The Right to Justification (New York, NY: Columbia University Press, 2012), 125-137; Young, Inclusion and Democracy, 31-33; Abizadeh, "Democratic Theory and Border Coercion," 39-42. Often, these authors see democracy and the protection of autonomy as related because, like Raz below, they take dependence on the arbitrary will of others to be inimical to autonomy. Hence, to the extent that having a democratic say reduces the arbitrariness of exercises of political power, it protects autonomy. Note that this is compatible with recognizing that having a democratic say is not sufficient to fully protect individual autonomy. The claim is rather that democratic inclusion is necessary to reduce the extent to which individuals' autonomy is compromised by subjection to arbitrary power.

${ }^{55}$ Joseph Raz, The Morality of Freedom (Oxford: Oxford University Press, 1986), 155.

${ }^{56} \mathrm{Ibid}, 153$.

${ }^{57}$ Ibid, 155-156.

${ }^{58}$ Abizadeh, "Democratic Theory and Border Coercion," 46; Kukathas, "The Case for Open Immigration," 210211.

${ }^{59}$ David Miller, "Immigration: The Case for Limits," in Contemporary Debates in Applied Ethics, ed. Andrew Cohen and Christopher Wellman (Malden, MA: Blackwell, 2005), 195. 
${ }^{60}$ Andrew Shacknove, "Who is a Refugee?," Ethics 95, no. 2 (1985).

${ }^{61}$ David Miller, "Why Immigration Controls Are Not Coercive: A Reply to Arash Abizadeh," Political Theory 38, no. 1 (2010): 117.

${ }^{62}$ James Hathaway, "Harmonizing for Whom? The Devaluation of Refugee Protection in the Era of European Economic Integration" Cornell International Law Journal 26(1993): 731.

${ }^{63}$ Sarah Fine, "Freedom of Association Is Not the Answer," Ethics 120, no. 2 (2010): 348.

${ }^{64}$ Miller, "Why Immigration Controls Are Not Coercive: A Reply to Arash Abizadeh," 117-118.

${ }^{65} \mathrm{Raz}$, The Morality of Freedom, 155.

${ }^{66}$ Arash Abizadeh, "Democratic Legitimacy and State Coercion: A Reply to David Miller," Political Theory 38, no. 1 (2010): 126.

${ }^{67}$ See Raz, The Morality of Freedom, 377; Abizadeh, "Democratic Theory and Border Coercion," 59. I avoid relying on their position for dialectical reasons. Against this position, Miller, "Why Immigration Controls Are Not Coercive: A Reply to Arash Abizadeh," 114-117, cites the example of a landowner who refuses entry to his faraway island by credibly threatening the use of force. This violates the Independence condition of all possible would-be immigrants, but intuitively does not seem to warrant granting everyone a right to determine the island's border policy on terms of equality. At the very least, then, Miller's thought-experiment casts doubt on the position endorsed by Raz and Abizadeh. Thus, although border controls would clearly be coercive if their position were correct, my argument's dialectical force is strengthened by the fact that it does not require that their position be correct.

${ }^{68}$ Thanks to an anonymous reviewer for pressing me here.

${ }^{69}$ E.g., UNHCR. "Asylum Trends." UNHCR - The UN Refugee Agency (2015), http://www.unhcr.org/cgibin/texis $/$ vtx $/$ search page $=\&$ comid $=4146 \mathrm{~b} 6 \mathrm{fc} 4 \& \mathrm{cid}=49 \mathrm{aea} 93 \mathrm{aba} \&$ keywords $=$ Trends .

${ }^{70}$ See, e.g., Young, Inclusion and democracy, 257-259, for this suggestion. 